Western Washington University

Western CEDAR

Spring 2009

\title{
Creating Social Capital in the Early American Republic: The View from Connecticut
}

Johann N. Neem

Western Washington University, johann.neem@wwu.edu

Follow this and additional works at: https://cedar.wwu.edu/history_facpubs

Part of the History Commons

\section{Recommended Citation}

Neem, Johann N., "Creating Social Capital in the Early American Republic: The View from Connecticut" (2009). History Faculty and Staff Publications. 2.

https://cedar.wwu.edu/history_facpubs/2

This Book Review is brought to you for free and open access by the History at Western CEDAR. It has been accepted for inclusion in History Faculty and Staff Publications by an authorized administrator of Western CEDAR. For more information, please contact westerncedar@wwu.edu. 


\section{Creating Social Capital in the Early American Republic: The View from Connecticut To Connec-} ticut's Congregational ministers, something had gone wrong. Hardly had independence been won when ordinary people began challenging elite authority at home. In the newer settlements of the Old Northwest, many former Connecticut residents did not even go to church, an activity that had long been at the heart of the commonwealth. Without religion, not only would individuals be condemned to live their lives without knowing God, but society would also dissolve as individualism and egalitarianism replaced the hierarchical organic social order that had long held people together. Something had to be done. People were starving for religion, and they needed access. Members of Connecticut's elite Standing Order, the small group of elected officials and statesupported ministers who had long presided over Connecticut, saw themselves as entrusted with the responsibility of looking out for the good of their fellow citizens. They would not let their emigrants down.

The Connecticut Missionary Society (CMS) was organized in I798, the same year as the passage of the Alien \& Sedition Acts, a time when Federalists felt under siege by the growing Jeffersonian Republican opposition. New England's ministers sought to remind their flock that the republic's future depended on preserving an organic social order. This social order also had to be built out West, where New England migrants were heading in record numbers to make new lives on land that was both plentiful and more fertile. There they faced what Roth called the fundamental "democratic dilemma," how to reconcile freedom with the need for order. The original trustees of the cms had the most to lose from the

Johann N. Neem is Associate Professor of History, Western Washington University. He is the author of Creating a Nation of Joiners: Democracy and Civil Society in Early National Massachusetts (Cambridge, Mass., 2008); "Squaring the Circle: The Multiple Purposes of Civil Society in Tocqueville's Democracy in America," Tocqueville Review, XXVII (2006), 99-I2I.

The author thanks Peter Onuf and an anonymous reader for their comments, and Katharine Neem Destler, Julie Dugger, Vicki Hsueh, Niall Omurchu, and Jennifer Seltz for thoughtful conversations.

(C) 2009 by the Massachusetts Institute of Technology and The Journal of Interdisciplinary History, Inc. 
egalitarian spirit of Jeffersonian republicanism. Like other voluntary associations of the time, the CMS was formed by elites. Since associations, like corporations, were public entities, it made sense that they would be run by public men. The trustees' goal was both to reassert their authority at home and to create a similar moral order in the fast-growing frontier. They were sincerely concerned with ensuring that their former citizens had access to religious teachings in their new western homes. ${ }^{1}$

Despite their intentions, however, the efforts of the CMS trustees in the West helped to create a civil society vastly different from the one in which they worked, and one that previewed what would soon happen in Connecticut. This article details the irony of how the attempt to preserve an old way of life resulted in a new one. ${ }^{2}$

\section{The prevailing assumption today is that voluntary associations}

I The most important study of the CMS is James R. Rohrer, Keepers of the Covenant: Frontier Missions and the Decline of Congregationalism 1774-1818 (New York, I995). See also Amy DeRogatis, Moral Geography: Maps, Missionaries, and the American Frontier (New York, 2003); Charles Roy Keller, The Second Great Awakening in Connecticut (New Haven, I942), 70-108. For the Federalists, see Joanne B. Freeman, "Explaining the Unexplainable: The Cultural Context of the Sedition Act," in Meg Jacobs, William J. Novak, and Julian E. Zelizer (eds.), The Democratic Experiment: New Directions in American Political History (Princeton, 2003), 20-49; Seth Cotlar, "The Federalists' Transatlantic Cultural Offensive of I 798 and the Moderation of American Democratic Discourse," in Jeffrey L. Pasley, Andrew W. Robertson, and David Waldstreicher (eds.), Beyond the Founders: New Approaches to the Political History of the Early American Republic (Chapel Hill, 2004), 274-299; Stanley Elkins and Eric McKitrick, The Age of Federalism (New York, I993); Linda K. Kerber, Federalists in Dissent: Imagery and Ideology in Jeffersonian America (Ithaca, I970); James M. Banner, Jr., To the Hartford Convention: The Federalists and the Origins of Party Politics in Massachusetts, 1789-1815 (New York, I970). Questions concerning the relationship between voluntarism and social order are raised in Randolph A. Roth, The Democratic Dilemma: Religion, Reform, and the Social Order in the Connecticut River Valley of Vermont, 1791-1850 (New York, 1987); Paul Boyer, Urban Masses and Moral Order in America, 1820-1920 (Cambridge, Mass., I978); DeRogatis, Moral Geography. On the idea of public trusteeship, see Neem, Creating a Nation of Joiners: Democracy and Civil Society in Early National Massachusetts (Cambridge, Mass., 2008), Io-80; Peter Dobkin Hall, Inventing the Nonprofit Sector and Other Essays on Philanthropy, Voluntarism, and Nonprofit Organizations (Baltimore, I992); idem, The Organization of American Culture, 1700-1900: Private Institutions, Elites and the Origins of American Nationality (New York, I982); Clifford S. Griffin, Their Brothers' Keepers: Moral Stewardship in the United States, 1800-1865 (New Brunswick, N.J., I960). Rohrer, Keepers of the Covenant, discounts the importance of Federalism and the fear of social disorder in shaping the Standing Order's actions but rightly points out that Connecticut's ministers were animated also by other, more noble, motivations, including their honest desire to help emigrating New Englanders receive God's word.

2 In The "Lively Experiment": The Shaping of Christianity in America (New York, I963), Sidney Mead noted the role of space and the frontier in shaping the development of America's religious and social institutions ( $\mathrm{I}-\mathrm{I} 5$, IO3-I33). 
foster shared norms, social solidarity, and civic engagement among ordinary people and that Americans are not forming enough of them. In Putnam's now famous phrase, people are "bowling alone." This article examines why and how one group of Americans came to think that bowling together was good for society. It looks first at how the elite trustees of the CMs learned to rely on voluntary associations to produce order out of chaos on the frontier and then how they, and other members of the Standing Order, followed a similar learning curve back home in the East. In essence, the members of Connecticut's Standing Order discovered that ordinary people could generate social capital. ${ }^{3}$

Social capital is a term with a complicated history and an often unclear meaning. The word capital suggests a conceptual correlation with the more traditional form of capital, money. Coleman and Bourdieu, the two most prominent theorists of social capital, both consider social a modification of capital. "Social capital," Coleman wrote, "is defined by its function." Its purpose is to "facilitate certain actions of actors." Like wealth, "social capital is productive, making possible the achievement of certain ends that in its absence would not be possible." Yet, unlike money, social capital "inheres in the structure of relations between actors and among actors." Because it is produced through interpersonal interaction, it cannot be stored by the actors themselves nor converted into physical things. Its generation requires people to be involved in networks that serve as tools allowing them to achieve their ends in society. People with abundant social capital are in a good position to draw from society's resources for their own benefit. $^{4}$

3 Robert D. Putnam, "Bowling Alone: America's Declining Social Capital," Journal of Democracy, VI (1995), 65-78; idem, Bowling Alone: The Collapse and Revival of American Community (New York, 2000). See also Theda Skocpol, Diminished Democracy: From Membership to Management in American Civic Life (Norman, 2003); Sidney Verba, Kay Lehman Schlozman, and Henry E. Brady (eds.), Voice and Equality: Civic Voluntarism in American Politics (Cambridge, Mass., 1995). For a skeptical appraisal, see Jason Kaufman, For the Common Good? American Civic Life and the Golden Age of Fraternity (New York, 2003); idem and David Weintraub, "Social Capital Formation and American Fraternal Association: New Empirical Evidence," Journal of Interdisciplinary History, XXXV (2004), I-36.

4 James S. Coleman, "Social Capital in the Creation of Human Capital," American Journal of Sociology, Supplement, "Organizations and Institutions: Sociological and Economic Approaches to the Analysis of Social Structure," XC (I988), S95-Si 20. For a historical overview of the idea of social capital, see James Farr, "Social Capital: A Conceptual History," Political Theory, XXXII (2004), 6-33; Steven Brint, "Gemeinschaft Revisited: A Critique and Recon- 
Bourdieu similarly defines social capital as "the aggregate of the actual or potential resources which are linked to possession of a durable network of more or less institutionalized relationships of mutual acquaintance and recognition-or in other words, to membership in a group." Social capital for Bourdieu, as for Coleman, is a resource from which an individual or class may draw to maintain or to achieve power within a particular society. ${ }^{5}$

The most prominent use of social capital today, however, comes from Putnam's study Bowling Alone. Following Coleman, Putnam argues that social capital is composed of the networks in which people are embedded, though, for Putnam, the benefits accrue not primarily to individuals but to communities. Social capital generates the "norms of reciprocity and trustworthiness" that make democratic public life possible. Life within "a dense network of reciprocal social relations" encourages people to do the kind of things for others that will eventually pay dividends for themselves. Social capital thus "lubricates social life" and checks egoistic individualism. In shifting the focus of social capital from the individual to the community, Putnam also makes the concept of social capital useful for those interested in how societies produce the shared norms and values that result in social solidarity. Such is the understanding of social capital invoked in this article. ${ }^{6}$

Putnam's conception of social capital, though distinctive, shares much with a long scholarly tradition that examines how a capitalistic and individualistic society like that of the United States manages to cohere at all. In his famous observations of American voluntarism, Tocqueville recognized that, among other functions, the associations of civil society encourage social solidarity and thus check what he considered to be an excessive American individual-

struction of the Community Concept," Sociological Theory, XIX ( 200I), I-23. My understanding of social capital also relies on Bob Edwards and Michael W. Foley, "Civil Society and Social Capital: A Primer," in Edwards, Foley, and Mario Dani (eds.), Beyond Tocqueville: Civil Society and the Social Capital Debate in Comparative Perspective (Hanover, N.H., 200I), I-I4; Skocpol and Morris P. Fiorina, "Making Sense of the Civic Engagement Debate," in idem (eds.), Civic Engagement in American Democracy (Washington, D.C., I999), 27-7I. See also Robert I. Rotberg, "Social Capital and Political Culture in Africa, America, Australasia, and Europe," Journal of Interdisciplinary History, XXIX (I999), 339-356- the introduction to a special double issue on the subject of social capital, entitled "Patterns of Social Capital," Journal of Interdisciplinary History, XXIX (Autumn and Winter I999), 339-782.

5 Pierre Bourdieu, "The Forms of Capital," in John G. Richardson (ed.), Handbook of Theory and Research for the Sociology of Education (Westport, I986), 24I-258.

6 Putnam, Bowling Alone, I9, 2 I. 
ism. In associations, Tocqueville wrote in Democracy in America, "feelings and ideas are renewed, the heart expands, and the human spirit develops only through the reciprocal action of human beings on one another." In other words, citizens who join associations glean an appreciation of community and the obligations that come with it. ${ }^{7}$

More recently, Bellah and his team, invoking Tocqueville, argued that Americans need to renew those "habits of the heart," and the institutions in which they are forged, in order to overcome the sense of alienation that seems to pervade American culture. They concluded that many Americans in the mid-I980s lacked the language to understand how their own well-being was intimately connected to that of others. Similarly, Wolfe advised a return to the lessons of the eighteenth-century Scottish theorists of civil society, whose primary contribution was to recognize "that people are capable of participating in the making of their own moral rules." In distinct ways, Tocqueville, Bellah, Wolfe, and Putnam all suggest that in civil society, ordinary people are the progenitors of the norms and values that enhance social solidarity, reconciling democratic freedom and social order. ${ }^{8}$

The assumption that shared norms and social solidarity can be produced by the voluntary actions of ordinary people is radical. In earlier centuries, Western thinkers believed that society was held together through a vertical hierarchy, a great chain of being that connected the lowly peasant to his lord and ultimately to his king and God. This chain sustained social solidarity through enforced inequality. In Tocqueville's view, aristocratic societies inherently connected people to each other, as well as to their ancestors and progeny, whereas democracies rip the "fabric of time," leaving people on their own, in the moment, in perpetual competition. The greatest dangers in ages of equality are alienation and a lack of

7 Alexis de Tocqueville (trans. Arthur Goldhammer), Democracy in America (New York, 2004; orig. pub. I835), 598. On this reading of Tocqueville, see Stefan-Ludwig Hoffmann, "Democracy and Associations in the Long Nineteenth Century: Toward a Transnational Perspective," Journal of Modern History, LXXV (2003), 269-299; James T. Kloppenberg, "Life Everlasting: Tocqueville in America," in The Virtues of Liberalism (New York, I998), 7I-8I. For a discussion of the multiple ways in which Tocqueville thought of associations, see Neem, "Squaring the Circle: The Multiple Purposes of Civil Society in Tocqueville's Democracy in America," Tocqueville Review, XXVII (2006), 99-I2I.

8 Robert N. Bellah et al., Habits of the Heart: Individualism and Commitment in American Life (Berkeley, I985); Alan Wolfe, Whose Keeper? Social Science and Moral Obligation (Berkeley, I989), I2. 
institutional barriers to state power, which invite tyranny. According to Tocqueville, a strong civil society could check these tendencies, not only because associations foster a more cohesive community but also because they act as a buffer against expanding state power. But Tocqueville's observations came at a time when voluntary associations had already started to spread, and many Americans had begun to learn his lessons.'

Scottish social theorists may have been among the first to articulate the idea of civil society as a self-regulating ethical realm. Francis Hutcheson and Henry Home, Lord Kames, believed that human beings were naturally social and moral. In The Theory of the Moral Sentiments and the Wealth of Nations, Smith argued that society and the economy could be, at least to a large degree, selfregulating. But New England's Standing Order was not easily convinced. To them, social order had to be imposed on an unruly population. Committed to an older organic idea of society, they did not initially accept the Scottish theorists' assertions. Only as their experience with voluntary associations grew, first on the frontier and then back home, did they become convinced otherwise. ${ }^{10}$

Recent research makes clear that New England's elite politicians and ministers, far from envisioning a civil society comprised of voluntary associations, were proponents of what Brooke called the "consensual public sphere," over which they would preside, reinforcing their authority through institutions and words. In response, egalitarian-minded Jeffersonian Republicans organized rival groups during the I790s - self-proclaimed and self-created "democratic societies" that challenged the Federalists' dominance of civil society. The people, Republicans averred, had the right to assemble, especially when their leaders threatened their liberties.

9 Tocqueville, Democracy in America, 586-587; I98-223, 595-609 (discussion of voluntary associations). On the hierarchical nature of colonial American society, see Gordon S. Wood, Radicalism of the American Revolution (New York, I99I), I I-92. See also Brendan McConville, The King's Three Faces: The Rise and Fall of Royal America, 1688-1776 (Chapel Hill, 2007).

Io Marvin B. Becker, The Emergence of Civil Society in the Eighteenth Century: A Privileged Moment in the History of England, Scotland, and France (Bloomington, I994); Wolfe, Whose Keeper? 27-ro4. On Smith, see John Dwyer, "Ethics and Economics: Bridging Adam Smith's Theory of Moral Sentiments and Wealth of Nations," Journal of British Studies, XL (2005), 662687; idem, The Age of the Passions: An Interpretation of Adam Smith and Scottish Enlightenment Culture (East Linton, Scotland, I998); Emma Rothschild, Economic Sentiments: Adam Smith, Condorcet, and the Enlightenment (Cambridge, Mass., 200I). 
The Republicans opened a space for self-organization in the I790s, but their unitary conception of "the people" made them generally fearful of privately organized entities, which they, like their Federalist opponents, suspiciously viewed as cabals, or special interests, opposed to the people's will. ${ }^{11}$

By overcoming these assumptions, civil society's architects ultimately carved out a realm of largely middle-class associations that generated the social capital that had once been (ideally) imposed from above. Missionary societies in the I79os and early I 800 s experimented with the voluntary model by founding churches in what they perceived as the anarchic West. The initial goal of the CMS was to re-create the consensual public sphere on the frontier, but frontier circumstances forced it to build a new kind of civil society, more like the modern version in which citizens create their own communal norms and social solidarity. Connecticut's Standing Order discovered that social capital could develop from below through the voluntary actions of ordinary people in horizontal relationships rather than the vertical hierarchical ties that had long defined the ideal social order. The frontier model ultimately found its way back East when the Federalist Standing Order lost state support and popular deference and thus had to adopt voluntary methods to achieve its ends. In Modern Social Imaginaries, Taylor defined modernity as the replacement of a natural, transcendent, timeless social order with a setting in which individuals establish their own order in secular time. Connecticut's elites, raised in the Puritan-Congregational tradition, had assumed the existence of a natural order. The American Revolution

I I John L. Brooke, "Ancient Lodges and Self-Created Societies: Voluntary Association and the Public Sphere in the Early Republic," in Ronald Hoffman and Peter J. Albert (eds.), Launching the Extended Republic: The Federalist Era (Charlottesville, 1996), 273-377. See also Neem, Creating a Nation of Joiners; Albrecht Koschnik, "Let a Common Interest Bind Us Together": Associations, Partisanship, and Culture in Philadelphia, 1775-1840 (Charlottesville, 2007); Christopher Grasso, A Speaking Aristocracy: Transforming Public Discourse in Eighteenth-Century Connecticut (Chapel Hill, I999); Elkins and McKitrick, Age of Federalism, 45 I-46I; Saul Cornell, The Other Founders: Anti-Federalism and the Dissenting Tradition in America, 1788-1828 (Chapel Hill, I999), I95-218. To Jefferson and his followers, associations remained dangerous. Although they agreed that people could generate their own social order, they preferred the civic community to the alternative communities of civil society. In Jefferson's ward republics, individuals would gather and forge consensus, whereas associations might fragment rather than enhance Americans' efforts to form a cohesive republican society. On ward republics and participatory democracy, see Garrett Ward Sheldon, The Political Philosophy of Thomas Jefferson (Baltimore, I991), 67-72. 
called this idea into question. An examination of how Connecticut's elite ministers learned how to create order from the bottom up reveals one aspect of how Americans became modern. ${ }^{12}$

EXPERIMENTING IN THE WEST In I764, the General Association of the Congregational Church in Connecticut established a committee to recruit and support missionaries in Vermont. Their missionary efforts gradually expanded to western New York, Pennsylvania, and Ohio. By the third decade of the nineteenth century, the missionaries were active throughout the western frontier. In I 800 , only 45,000 persons lived in Ohio; in I $8 \mathrm{IO}$, the population reached 23I,000. Not all these residents were from Connecticut, but many of them were, especially in the Ohio area known as the "Western Reserve." In I792, the General Association, the primary body of Connecticut ministers, asked the state assembly for financial assistance, realizing that the missionary needs of frontier settlements were greater than they had anticipated. They were not alone. The Massachusetts and New York missionary societies engaged in similar activities. By I 8 Io many denominations had local and regional missionary organizations of their own. The frontier became the site for both denominational competition and the transfer of eastern social, cultural, and financial capital. ${ }^{13}$

The missionary efforts of the General Association did not grow out of a vacuum. Letters from Connecticut's emigrants in the northern or western frontiers often noted the difficulty of securing and supporting a Congregational minister. The absence of ecclesiastical institutions was certainly a source of frustration for many of the settlers who had come from a state with an established church. The General Association received numerous requests for assistance. A group of settlers from Surlough County in the Otsego region of New York wrote, "We ... [are] desirous to have the gospel preached among us and not being able to support a preacher on account of our juvenile state in Agriculture." In Vermont, a state notorious for its democratic tendencies, a group of

I2 Charles Taylor, Modern Social Imaginaries (Durham, 2004).

I 3 United States Department of Commerce, Department of the Census, Historical Statistics of the United States: Colonial Times to 1970 (Washington, D.C., I975), I, Series A, I95-201; Virginia and Robert McCormick, New Englanders on the Frontier: The Migration and Settlement of Worthington, Ohio (Kent, Ohio, I998); Robert A. Wheeler, "The Literature of the Western Reserve," Ohio History, C (I99I), IOI-I28.On the distinctions between social, cultural, and financial capital, see Bourdieu, "Forms of Capital." 
settlers thanked the "Revd Association in Connecticut" for sending someone "to preach to the vacant towns in the northerly part of the state of Vermont," although their letter also acknowledged that many Vermonters resisted the missionary efforts of the Connecticut establishment: "Certain men, in these parts, have treated the Revd. Mr. Smith very disrespectfully." Nonetheless, they hoped that this "incivility [would] not abate the arder [sic] of [the General Association's] benevolence and zeal in the least." 14

Such communications reminded the General Association of the importance of their missionary activity but also made them aware of the extent of the problem. Frontier settlers could not found and maintain churches. In I798, the General Association established the CMS to better address this problem. The new society emphasized that its intent was to provide Connecticut's frontier settlements with ministerial teachings and to promote "the order and stability of civil government" there. The CMs' roots lay as much in their own fears about frontier settlements as in their awareness of the Congregational church's structural needs. The settlers' lack of funds and ministers meant that they could not remain tied to the church without the aid of Connecticut money. ${ }^{15}$

Not withstanding its good intentions, the CMS associated social order with its own religious teachings, wary of the growing strength that other churches were showing, both at home and on the frontier. Settlers exploited the trustees' distrust of other denominations. For example, one congregation in Vermont explained, "The Town is of so many various denominations as it makes but as it were few of the Congregational order . . . [and] there being no settled minister of the order for a great distance thus we seem to be as sheep without a shephard [sic] and are in danger of being scattered." Another letter written in I8I 5 from Seneca Falls, New York, noted that in their village, "A very small

I4 Residents in Surlough County, Otsego, New York, to Connecticut Missionary Society, June I3, I793, in Missionary Society of Connecticut Papers (hereinafter CMS papers) (Glen Rock, N.J.), Reel I3 of 20; from Georgia, Vermont, Aug. 30, I793, ibid.

I5 Constitution of the Missionary Society of Connecticut, June 21, I798, CMs Papers, Reel I6; An Address of the General Association to the Good People of Connecticut, June 2I, I798, ibid.; Rohrer, Keepers of the Covenant, I5-52. In The Transformation of Charity in Postrevolutionary New England (Boston, I992), I07-I I I, Conrad Edick Wright argues that New Englanders' awareness of social problems emerged only after they formed organizations. By identifying a problem and creating an organization, the extent and nature of that problem became more visible than it was before. 
portion ... pay any regard to the preaching of the word, in addition we have mixed among us a society of Methodists \& Baptists, so that the number willing to support the Presbyterian system in English is very small" (the reference to English was due to the large number of Germans who inhabited the village). ${ }^{16}$

Connecticut's frontier settlers desired more than just occasional missionaries. Unlike Methodists, who relied on itinerant circuit riders combined with local meetings, Congregationalists and Presbyterians expected and needed settled pastors. As frontier congregations gained strength and stability, they petitioned the CMS for permanent clergy. The trustees first confronted this issue in I 800 when the Rev. Seth Willington, who was in their employ, requested permission to reduce his missionary service on behalf of the CMS to half of the year so that he could spend the other half meeting the needs of a parish in General Matthew Patterson's settlement. The trustees complied with the request, but imposed four conditions; (I) that each of his missionary tours last at least four weeks; (2) that the district in which his missionary work took place be determined by the CMS; (3) that he continue to send reports about his missionary work; and (4) that this new arrangement last no more than a year. ${ }^{17}$

The CMS response suggests, on the one hand, that the trustees understood the importance of settled ministers - the very the heart of the Congregational system. In fact, their earliest efforts to recruit missionaries during the I790s proved unfruitful because many settled ministers refused to leave their stations, and many congregations were unwilling to permit them to do so. On the other hand, the CMS wanted to retain control of its missionaries and to serve as many people as possible on a limited budget. By establishing the terms in Willington's case, the CMs hoped that his missionary efforts would continue to meet the exigencies of the frontier. ${ }^{18}$

Part-time missionaries like Willington soon became the norm. The CMS discovered that it could hire more missionaries if it shared the financial burden with capable frontier congregations.

I6 From Monkton[?], Vt., Feb. 25, I800, cms Papers, Reel I3; from Seneca Falls, Jan. Io, I8 I s, ibid.

I7 Board of Trustees minutes, May 7, I800, CMs Papers, Reel I4.

I8 See the incoming correspondence, CMs Papers, Reel I3. For discussion, see Rohrer, Keepers of the Covenant, 37-39. 
Ministers often would be in CMS employ half the time and settled during the other half. In I $8 \mathrm{II}$, the CMS approved a request by a congregation in Burton, Ohio, on the condition that if they "should procure a man to settle with them ... who is approved by this Board or the Committee of Missions, the said minister shall be appointed a missionary, and be allowed eight dollars per week for the time that he shall labor as a missionary." In other words, the CMS desired to be responsive to the needs of congregations on the frontier while retaining oversight of the missionaries on its payroll. ${ }^{19}$

At stake was the nature of civil society. Rather than a corporatist, covenanted community, frontier religion was voluntary. No established church existed in either Vermont or Ohio. Some Vermonters sought to re-create the hierarchical social order of older New England but could not implement this vision when faced with the egalitarian assumptions and the religious diversity of the state's settlers. During the constitutional convention of 1802 in Chillicothe, Ohio, the question of religion attracted little discussion. Even if Ohioans had desired to establish a state religion, they would have had trouble choosing one from the various denominations gaining adherents in the state. Moreover, each denomination and sub-denomination had the financial assistance of a national organization, such as the Presbyterian Missionary Society (I 799), the Baptist Missionary Society of Massachusetts (I 802), and the committee on missions in the Presbyterian General Assembly (I 802), not to mention the CMS. ${ }^{20}$

Despite these organizational and institutional changes, a civil society built on voluntary associations was hardly self-evident in the eyes of the elite trustees of the CMS in Hartford. For one thing, Connecticut retained much of its inherited civic culture. The church, for example, received tax support until i8 18. More important, the division between voluntary associations and public office had not yet taken place. The CMS remained a public organi-

I9 Trustees minutes, Jan. 2, I8 II , CMS Papers, Reel I4.

20 Roth, Democratic Dilemma, 3 I-79. Federalist William Cooper also sought to use associations to re-create a hierarchical social order in Cooperstown on the western New York frontier. See Alan Taylor, William Cooper's Town: Power and Persuasion on the Frontier of the Early American Republic (New York, I995), 205-2I7. Journal of the Convention of the Territory of the United States Northwest of the Ohio ... (Chillicothe, Ohio, I802); Lois Banner, "The Protestant Crusade: Religious Missions, Benevolence, and Reform in the United States, I790-1840," unpub. Ph.D. diss (Columbia Univ., I970). 
zation, even after it was disconnected from the General Association. Its trustees were either prominent (and Federalist) politicians or established ministers. Jonathan Treadwell (I745-I823), its first chairman, was lieutenant governor from I 8OI-I 809 and then governor for one term. He was also a member of the Governor's Council, the Continental Congress, and the Yale Corporation; a deacon in his local church; and a delegate to the infamous Hartford Convention that urged New Englanders to rethink the value of their membership in the United States. Jonathan Brace (I754I 837), the second chairman, had a similar career, serving five years in the state legislature, as well as stints in the Governor's Council and in various judgeships. Oliver Ellsworth (I745-I 807), another trustee and member of the Governor's Council, was a congressman from I 777 to $\mathrm{I} 783$, an attendee at the Constitutional Convention in 1787 , a judge on the Supreme Court of Connecticut and, from 1796 to I 800 , Chief Justice of the United States. ${ }^{21}$

These men believed in and embodied the consensual public sphere. The position of CMS trustee was simply an extension of their public duty. Trusteeship was as much a public office in Connecticut during this era as was the ministry itself. When the CMS was chartered in I8OI, this connection became even more explicit. Corporate charters in early national New England created state agencies; the charter was a grant of state privilege for public work. By being incorporated, the CMs confirmed its work as being in the public interest and approved by the people's elected representatives. Between I 800 and I830, more than half of the CMS annual income came from donations in parishes by act of the state legislature. ${ }^{22}$

The trustees imagined that the civic culture in which they operated could be approximated on the frontier, although they were never naive enough to think that they could reproduce Connecticut exactly in Ohio, especially after I 80 I when the governance of the territories was under the national Republican administration. As early as I798, the North Association of Hartford

2I Biographical information from J. T. White (ed.), National Cyclopedia of American Biography (New York, I895-I984).

22 Oscar and Mary Flug Handlin, Commonwealth: A Study of the Role of Government in the American Economy: Massachusetts, 1774-1861 (Cambridge, Mass., I969); Hall, "Organizational Values and the Origins of the Corporation in Connecticut, I760-1860," Connecticut History, XXIX (1988), 63-90; Purcell, Connecticut in Transition, 204-206. 
County suggested that the difference between Ohio and Connecticut raised concerns about the moral future of society. In its message to "the piously and benevolently disposed," the Association called for donations to support the new CMS missionary efforts. Reminding Connecticut citizens that the frontier settlers "are our brethren, children and friends," they pointed out that settlers could not "defray the expenses of the regular administration of the gospel." More important, the North Association insisted that the existence of a moral, corporate society hung in the balance: "Many of them [the new settlers] look back, with painful anxiety, to the evangelical privileges which they enjoyed while among us, and are ready to weep at their destitute condition. The happiness of our new-forming settlements, rapidly rising in the wilderness, the order and stability of government in future times, the general welfare of the rising generation, and indeed of civil society, call loudly for charitable assistances." 23

The North Association clearly believed that frontier settlements in regions like Ohio and Vermont were very different from Connecticut; they were qualitatively inferior. After all, if churches were necessary elements of a moral society, the state was obligated to support them. Frontier settlers could not afford to establish a church for the simple reason that they lacked tax support and had to compete with other denominations. Hence, the North Association understood that it would take effort from settlers to retain the benefits of their home state's institutions within a vastly different context.

The CMS trustees hoped to check the egalitarian frontier spirit that threatened their preferred social order. In the absence of sufficient missionaries, the trustees sought to distribute books and printed sermons for Congregationalists to use in their services. Unlike the egalitarian-minded Baptists and Methodists, Congregationalists remained convinced that the church, like society, rested on authority. In I795, the General Association urged frontier Congregationalists to gather for worship, "reading the scrip-

23 For an intriguing discussion of the CMs' effort to recreate its ideal social order in a frontier setting, see DeRogatis, Moral Geography. Andrew R. L. Cayton, "Radicals in the "Western World': The Federalist Conquest of Trans-Appalachian North America," in Doron BenAtar and Barbara B. Oberg (eds.), Federalists Reconsidered (Charlottesville, I998); "The North Association of Hartford County: To the Piously and Benevolently Disposed within Our Limits," October 4, I797, cms Papers, Reel I3. 
tures and the best sermons [that they could] obtain"-the "best sermons" being those shipped to them by the CMS whenever possible so that they would not have to rely on their own authority but could draw from the religious teachings of the Standing Order, replicating as best they could the religious experience of the hierarchical society that they had left. ${ }^{24}$

By I 8 I 7, the tone of the CMS remained somber, but a new solution was in the works. In a statement written by a committee that included the Revs. Timothy Dwight and Lyman Beecher, the CMS contrasted Connecticut, where "institutions and habits are good, [and] . . . operate as so many checks upon the corrupt propensities of our nature," to the frontier where settlers were "alone in the wilderness," lacking any "public eye" to watch over them and no "moral institutions" to ensure social order. What is most striking about this address is not that the Standing Order showed concern about frontier society but that the CMS seemed to be counting on voluntarism to check moral degradation. Noting that "human depravity is ever impatient of restraints" and therefore requires "strong barriers," the authors implored the settlers "by all means [to] unite, form churches and societies, as early as possible." Perhaps voluntary religious and moral societies could act in lieu of the established church and the corporate Standing Order. ${ }^{25}$

The CMs trustees' urgency may have been fueled, in part, by their growing awareness of the challenges of forging social order in the "wilderness." In I 8I 2/I3, the CMS, in cooperation with the Missionary Society of Massachusetts, sent Samuel J. Mills and John D. Schermerhorn, both graduates of Andover, to measure the charitable needs of frontier settlers. Their findings were troubling to committed philanthropists in New England. Mills and Schermerhorn suggested not only that the moral condition of frontier settlements was weakened by the dearth of churches (although Methodists and Baptists certainly had a strong presence) but also that many houses lacked even a Bible. Their report shows how the CMS trustees came to ascertain frontier needs; it also acted as a spur for local Bible and tract societies. ${ }^{26}$

24 Quotation and discussion from Rohrer, "The Connecticut Missionary Society and Book Distribution in the Early Republic," Libraries \& Culture, XXXIV (I999), I7-26.

25 General Association of Connecticut, An Address to the Emigrants from Connecticut, and from New England Generally, in the New Settlements in the United States (Hartford, I8I7).

26 Colin B. Goodykoontz, Home Missions on the American Frontier, with Particular Reference to the American Home Missionary Society (Caldwell, Idaho, I939). 
The success of the CMs, however, suggested new possibilities. The Society's roots may have lain in solving the specific problem of limited resources on the frontier, but by the I 820 s it had managed to enlist a large group of missionaries and to establish many churches; it had become proficient at organizing and distributing people and money. Although its trustees remained tied in theory to the inherited civic culture of Connecticut, they were proving that organized voluntarism could build social capital. The theory behind the established church - that it was necessary for republican government-could be changed. In their I8I7 announcement, the trustees suggested that the burden of responsibility could be shifted to individuals and families acting through voluntary organizations. The trustees' exhortation that frontier settlers "unite" "by all means" was not empty rhetoric. Without a state to act as agent, the settlers themselves (in association with organizations like the CMS) would inherit the responsibility of establishing moral institutions.

THe Struggle BaCK HOME Although Connecticut's Standing Order was organizing frontier society on a new, voluntary basiscomposed of the consensual actions of free, equal citizens-it fought to protect the hierarchical organic social order at home. By I 8 I 8, every state except Connecticut, New Hampshire, and Massachusetts had disestablished the church. In an effort to appease dissenters, Connecticut Federalists had passed "An Act for the Support of Religion and Literature" in October I8I6. The act proposed to divide the money owed Connecticut by the federal government for war expenses between, in descending order, Congregationalists, Episcopalians, Baptists, Methodists, and Yale. Federalists hoped to enable continued state support of religion by making monetary distribution available to all denominations. According to McLoughlin, this tactic "proved to be the worst blunder the Federalists could possibly have made." It enabled their Republican opponents, united with Episcopalians and other dissenters under the Republican-Toleration party, to win the I8I7 elections. ${ }^{27}$

The bill favored Congregationalists and left out such smaller

27 William G. McLoughlin, New England Dissent: 1630-1833: The Baptists and the Separation of Church and State (Cambridge, Mass., I97I), II, I034; II, I025-I062 (discussion of disestablishment). See also Richard J. Purcell, Connecticut in Transition: 1775-1818 (Middletown, I963), 2 I I-264. 
denominations as Quakers and Universalists. Baptists and Methodists, who emphasized the importance of absolute separation of church and state, took the unequal distribution of money as an affront. Republican victory led to a constitutional convention and ultimately disestablishment in I8 8. Such is the context in which the CMS trustees viewed the contrast between Ohio and Connecticut in their address. The chaos that they hoped to overcome in Ohio was now becoming a reality in their home state. The moral and good institutions that Connecticut exported to the new settlements were under fire, and the civic culture of Ohio seemed to signify the future.

Following disestablishment, the former Standing Order had no choice but to embrace the methods that had appeared in the West. The reaction of the Rev. Lyman Beecher, who had been one of the most vocal proponents of the old order, provides insight into this intellectual transformation. In I8I2, he convinced his fellow ministers to organize the Connecticut Society for the Promotion of Good Morals (CSPGM). In his inaugural sermon, "A Reformation of Morals Practicable and Indispensable," Beecher reiterated that social order was imposed from the top down, calling for the old moral laws to be re-invigorated. He argued for "restraint" and against "[conciliating] the favour of the flagitious." 28

Beecher blamed a misplaced Jeffersonian confidence in the people's natural goodness for the breakdown of order, mocking "the imported discovery, that human nature is too good to be made better by discipline, that children are enticed from the right way by religious instruction, and driven from it by the rod, and kept in thraldom [sic] by the conspiracy of priests and legislators." These attacks against authority threatened Connecticut's "ancient institutions." He implored Connecticut's ministers to challenge them: "Our fathers" understood that "man is desperately wicked, and cannot be qualified for good membership in society" without the cooperation of "pastors and churches, and magistrates." $\mathrm{He}$ described Connecticut's old order as "the most perfect state of society, probably, that has ever existed in this fallen world." Con-

28 On the formation of the CSPGM, see Mead, "Lyman Beecher and Connecticut Orthodoxy's Campaign against the Unitarians, I819-1826," Church History, IX (1940), 222-223; Keller, Second Great Awakening in Connecticut, I43-I 5O. For a discussion of Beecher's early efforts at forming voluntary associations, see McLoughlin, New England Dissent, II, I029-I032. 
necticut's salvation lay in "upholding those institutions and habits" that had long sustained the social order.

How to do it? According to Beecher, the only way was for Connecticut's "wise and good men"-the elite-to "diffuse" moral instruction by forming local associations and instilling a sense of shame into an immoral population. Recognizing that the state was no longer a reliable ally, given the ascendance of the Jeffersonians, Beecher urged each community's virtuous elite to "create a public opinion, which nothing can resist." Arguably, Beecher's recognition of the importance of public opinion was a genuine innovation - as he was to claim in his Autobiography - but his commitment to a hierarchical social order premised on authority certainly was not. In his view, public opinion was the domain of the few, not the many. ${ }^{29}$

Beecher vociferously opposed the separation of church and state, hoping instead to reinforce the established church. In his sermon "Building Waste Places," he urged his fellow ministers in Connecticut to form a missionary society to ensure that all of Connecticut's parishes would have their own minister. In essence, Beecher was proposing that they adopt the same methods at home that were used on the frontier. He believed that only the law could ensure religiosity; "mere voluntary associations," or voluntary religion, could never succeed. Voluntarism would "undermine the deep-laid foundations of our civil and religious order." 30

Despite his initial fears, however, Beecher later conceded that disestablishment had been a blessing in disguise, enhancing rather than undermining the social influence of religion. "By voluntary efforts, societies, missions, and revivals," he wrote, ministers "exert a deeper influence" than before. Following his conversion to voluntarism, Beecher helped to ease the transition from the

29 Beecher, A Reformation of Morals Practicable and Indispensable, a Sermon Delivered at NewHaven on the Evening of October 27, 1812 (Andover, I8I4; repr. in Edwin S. Gaustad [ed.], Lyman Beecher and the Reform of Society: Four Sermons 1804-1828 [New York, I972]); idem (ed. Barbara Cross), Autobiography of Lyman Beecher (Cambridge, Mass., I96I), I, I9I. For a critical assessment of Beecher's memory, see Keller, Second Great Awakening, 6I-62, I45-I46; for a discussion of Beecher as innovator, Donald M. Scott, From Office to Profession: The New England Ministry, 1750-1850 (Philadelphia, I978), 32-34; for a nuanced examination of New England ministers' approach to public opinion, Neil Brody Miller, "Proper Subjects for Public Inquiry: The First Unitarian Controversy and the Transformation of Federalist Print Culture," Early American Literature, XLIII (2008), IOI-I35.

30 Beecher, Autobiography, 200-20I. On Beecher's domestic missionary efforts, see Keller, Second Great Awakening, I05-Io8. 
old, organic social order to the new, voluntary regime of ordinary people - not just of the wise and the good-replicating in Connecticut what the CMS had done out West. ${ }^{31}$

The transformation in Beecher's and, more generally, the former Standing Order's understanding of how to bring order to a democracy is evident in a comparison between the two phases of the sabbatarian movement. The first phase began in I8Io when Congress mandated that post offices be open whenever mail arrived, including Sunday. The law challenged Connecticut's social order, in which all citizens ideally attended their local Congregational church on the Sabbath. By I8I4, Connecticut's ministers had joined the national protest, initiated by the Presbyterians, sending a petition to Congress demanding repeal of the law. By the end of I8I5, approximately Ioo such petitions had reached Congress from various parts of the country. Purporting to be from the residents of particular towns, these petitions were probably signed by congregants at the request of their minister. The process reinforced the existing order, emanating from the top of the church hierarchy and claiming to speak for an entire, unified community. ${ }^{32}$

By I 826, however, the religious community devised a new strategy that depended less on the structure of existing institutions than on support recruited from people at large. The Presbyterian General Assembly urged boycotts of any transportation company traveling on the Sabbath. In I 828, during "Anniversary Week"an annual meeting of the trustees from such national voluntary associations as the American Tract Society, the American Bible Society, and the American Sunday School Union in New York City-the Presbyterian elder Josiah Bissell, Jr., convinced the ministers present to launch a crusade to protect the Sabbath. The result was the formation of the General Union for the Promotion of the Christian Sabbath (GuPCS). Beecher was one of the founding members.

\footnotetext{
3 I Beecher, Autobiography, 253.

32 Richard R. John, "Taking Sabbatarianism Seriously: The Postal System, the Sabbath, and the Transformation of American Political Culture," Journal of the Early Republic, X, (I990), $538-539,542-543$ (petition numbers). For sabbatarianism, see also Bertram Wyatt-Brown, "Prelude to Abolitionism: Sabbatarian Politics and the Rise of the Second Party System," Journal of American History, LVIII (I97I), 3 I6-44I; Rohrer, "Sunday Mails and the ChurchState Theme in Jacksonian America," Journal of the Early Republic, VII (I987), 53-74.
} 
On the face of it, the GUPCS looked much like earlier associations, formed by a national elite composed mostly of ministers. But, as John argues, the GuPCS, unlike the earlier effort to enforce the Sabbath, was "unabashedly democratic — and, indeed, almost populistic." The GUPCS appealed directly to the people. Any person could become a member by pledging to boycott transportation companies that violated the Sabbath. Instead of relying on the authority of church leaders alone, the new organization sought to change, in Beecher's words, "public sentiment" by addressing the public's conscience and judgment. Unlike in I8I2, this time Beecher disavowed the use of state "coercion," instead urging his fellow citizens to observe the Sabbath and to boycott violating businesses voluntarily. Each citizen, not the state nor even the Standing Order, had the duty to ensure that public morality be preserved. ${ }^{33}$

The result of this new effort was impressive. By I 829, 467 petitions had reached Washington urging Congress to repeal the rule; by I83 I, the number had topped 900. Ministers mobilized citizens so effectively that for a few years, the GUPCS claimed more than I percent of the American population. The sabbatarian movement spoke in the name of, and relied on the consent and actions of, ordinary people in concert. It taught many Americans that they could shape the social order. ${ }^{34}$

The GUPCS is one of many institutions that comprised what is often called "the Benevolent Empire." During the I8Ios and I 820 , new societies emerged throughout Connecticut and the nation-including the American Bible Society, the American Tract Society, the American Temperance Society, and the American Sunday School Union. In I 829, the American Temperance Society claimed more than Ioo,ooo members. Griffin counted

33 John, "Taking Sabbatarianism Seriously," 538. A similar story can be told for the antimasonic movement of the late I820s/early i83os. As Steven C. Bullock, Revolutionary Brotherhood: Freemasonry and the Transformation of the American Social Order 1730-1840 (Chapel Hill, I996), argues, antimasonic leaders-many of whom were sabbatarians as well- transformed the public sphere by placing "public opinion and conscience at the heart of their thinking" (294-295).

34 [Beecher], The Address of the General Union for Promoting the Observance of the Christian Sabbath, to the People of the United States, Accompanied by Minutes of the Proceedings and in its Formation... (New York, I 828); John, "Taking Sabbatarianism Seriously," 538. The I \% statistic is from Skocpol, Diminished Democracy, 26-28. 
I,000 antislavery societies, 900 Bible societies, and 3,000 tract societies in $1839 .{ }^{35}$

Though often founded by elites, these new national organizations differed from the CMS in their reliance on the unpaid services of middle-class male and female volunteers at the local level. For example, the American Bible Society (ABS), despite its financial dependence on its auxiliaries, was more than simply an umbrella organization. Like the CMS, it sought to build social capital. Its trustees hired agents to meet with local citizens to form auxiliaries. The increase in Bible societies and tract societies at the local level reflected both local responses to national problems by an evangelical middle class and the efforts of national or regional elites to foster a vibrant voluntary sphere by teaching citizens how to form their own associations. What leaders of the ABs and other national reform networks discovered was that appeals to ordinary people could actually work. ${ }^{36}$

Many historians have seen little difference between the voluntary crusades that started in the I8Ios and the Standing Order that preceded them, largely because they were initiated by a ruling elite. The Standing Order's Republican opponents came to much the same conclusion. Critics of the social-control thesis respond that it grants too much power to elites and too little agency to ordinary people, treating as conspiracy the avowed positions of ministers and other citizens and discounting what evangelical ideas meant to people at the time. Many scholars fail to realize, however, that disestablishment and the subsequent spread of massmembership, voluntary associations created a social order that was fundamentally different from the old one. Even if Beecher's observation that ministers were more influential following disestablishment is correct, citizens were no longer taught to defer blindly to authority - whether that of church or state-but were invested

35 For the development of voluntary associations in Connecticut, see Keller, Second Great Awakening, I09-I87. For numbers, see Robert H. Abzug, Cosmos Crumbling: American Reform and the Religious Imagination (New York, I994), 86-90; Ronald G. Walters, American Reformers, 1815-1860 (New York, 1978), I26-I27; Griffin, Their Brothers' Keepers, 83.

36 Mary P. Ryan, Cradle of the Middle Class: The Family in Oneida County, New York, 17901865 (New York, I98I); Peter J. Wosh, Spreading the Word: The Bible Business in NineteenthCentury America (Ithaca, I994), 62-88; Neem, Creating a Nation of Joiners, 8I-I I3; Wright, Transformation of Charity, 96-I I I. See also American Tract Society, "The American Colporteur System" (New York, I836). 
with the authority once held by elites. The message that ministers preached had changed from complete obedience to personal initiative. Society was formed through horizontal connections between free and equal citizens rather than through the vertical connections that had been the Standing Order's original stock in trade. Ordinary Americans had become active participants in forging social order and communal norms. ${ }^{37}$

This new order, however, had limits. As many scholars have noted, it was fundamentally middle-class. Voluntary associations not only helped form middle-class identity; they also served as vehicles to impose middle-class norms on minorities and lower-class workers, especially immigrants. But to many middle-class Americans, the opportunity to cultivate their own social order was liberating and, compared to the ancien regime, egalitarian. It also meant that the form the social order was to take could and would be an object of civic concern and deliberation. The new social order could thus be subject to the challenges of motivated citizens on the same grounds as those who sustained it. If the social order was not divinely ordained, citizens could turn to voluntary associations to transform it even further. Americans undertook their new responsibilities with earnest seriousness-hence the myriad outreach efforts by middle-class Americans to the poor and immigrant populations. They recognized that the social order could be changed by their own actions, whether for such conservative purposes as sabbatarianism and temperance, or for such radical ones as abolition and female suffrage. The moral order, Americans discovered, was their own creation, not just something inherited and eternal. This was indeed something new under the sun, a new civil society with a radical foundation even if it was often employed for conser-

37 On Republicans, see Rohrer, Keepers of the Covenant, 62-69; New London Bee, 22 July I80I. Variations in approach to the social-control question include Griffin, Their Brothers' Keepers; Charles Foster, An Errand of Mercy: The Evangelical United Front, 1790-1837 (Chapel Hill, I960); Boyer, Urban Masses and Moral Order; Paul E. Johnson, A Shopkeeper's Millennium: Society and Revivals in Rochester, New York, 1815-1837 (New York, I978); Christine Stansell, City of Women: Sex and Class in New York, 1789-1860 (New York, I986). See also R. J. Morris, "Voluntary Societies and British Urban Elites, I780-I850: An Analysis," Historical Journal, XXVI (I983), 95-Ii8. For critical assessments, see Daniel Walker Howe, What Hath God Wrought: The Transformation of America, 1815-1848 (New York, 2007), I64-202; Banner, "Religious Benevolence as Social Control: A Critique of an Interpretation," Journal of American History, LX (I973), 23-4I; Thomas Haskell, "Capitalism and the Origins of the Humanitarian Sensibility, Part One,” American Historical Review, XC (I985), 339-36I. 
vative purposes. In Scott's words, by the I 820s, ministers and their evangelical supporters had developed "a whole new social grammar-a new and distinctive way of perceiving how the social order was composed, operated, and maintained." 38

Abolitionists took this lesson to heart. Rather than appealing solely to lawmakers, as elite antislavery advocates like Benjamin Franklin had done after the American Revolution and as the eliterun American Colonization Society continued to do, abolitionists formed voluntary associations in towns across the North and the West. By I838, the American Anti-Slavery Society claimed more than I, 300 auxiliary associations. Throughout Connecticut and the nation, abolitionists mobilized women and men from ordinary backgrounds. Activists signed petitions, attended lectures, donated money and time, and sought to convert their neighbors. Abolitionists explicitly sought to alter the social order from the bottom up, even in the face of intense hostility from political elites and many ministers. The new civil society could both forge social order and disrupt it, since it was subject to the deliberative processes of the citizenry. ${ }^{39}$

From this perspective, the theological conflicts within New England Congregationalism become more comprehensible. Many Congregationalists felt the need to adapt the authoritarian Calvinist God to one more compatible with a democratic social order. During the revivals of the Second Great Awakening, sympathetic ministers emphasized the fact that ordinary people could save themselves. Although some ministers may have tried to sustain the idea of an omnipotent god who dispensed grace by predestination, Americans were being taught that by attending revivals, joining churches, and participating in voluntary associations, they could save themselves and their society. As New England's divines

38 Anne M. Boylan, The Origins of Women's Activism: New York and Boston, 1797-1840 (Chapel Hill, 2002); Stuart M. Blumin, The Emergence of the Middle Class: Social Experience in the American City, 1760-1900 (New York, 1989), 192-229; John S. Gilkeson, Middle-Class Providence, 1820-1940 (Princeton, I986); Ryan, Cradle of the Middle Class; Stansell, City of Women; Scott, From Office to Profession, 36-5I.

39 The best study of the abolitionists' strategies is Richard S. Newman, The Transformation of American Abolitionism: Fighting Slavery in the Early Republic (Chapel Hill, 2002). See also Susan Zaeske, Signatures of Citizenship: Petitioning, Antislavery, and Women's Political Identity (Chapel Hill, 2003); Neem, Creating a Nation of Joiners, I63-I70. 
adapted to modernity, they also helped to lay its theological foundations. ${ }^{40}$

However hesitantly, Connecticut's leaders finally embraced the new civil society that they had fostered in the West. The founding of voluntary churches and other associations became the dominant strategy to produce moral order and social capital in the United States. Once the type of hierarchical authority exemplified by the Standing Order, as abetted by state legislation, had dissolved, America's ministers and ordinary citizens had no choice but to adapt.

In Vermont, voluntary associations provided a vehicle for communitarian-minded citizens to forge social cohesion without the coercive mechanism of the state, thus producing order without offending the egalitarian sentiments of post-Revolutionary Americans. Doyle's study of a nineteenth-century frontier Illinois town demonstrates the important role that settlers assigned to voluntary associations in integrating a disorderly and often divided community. Utica, New York, also generated communal norms through voluntary associations. As Mathews suggested, the Second Great Awakening was an "organizing process" by which religious leaders sought to use associations to create order in a country undergoing dramatic economic, social, and geographical change. Similarly, residents newly arrived in American cities, whether from farms or foreign countries, could find themselves living in an atomistic environment, sorely missing the social institutions that had once held them in place. Voluntary associations often filled the void for them. Wherever it emerged, the new order combined Revolutionary egalitarianism with the recognition that all societies require shared values and norms. ${ }^{41}$

40 On modernity and theological foundations, see especially Scott, From Office to Profession, 36-5I; in relation to individuals, Sidney Mintz, Moralists and Modernizers: America's Pre-Civil War Reformers (Baltimore, I995). See also Howe, What Hath God Wrought, I66-I76; Mark A. Noll, America's God: From Jonathan Edwards to Abraham Lincoln (New York, 2002); Nathan O. Hatch, The Democratization of American Christianity (New Haven, I989); Joseph Haroutinian, From Piety to Moralism: The Passing of the New England Theology (New York, 1932); Keller, Second Great Awakening, 224-230. On the effort of theologians to sustain Calvinism amid change, see William Breitenbach, "The Consistent Calvinism of the New Divinity Movement," William and Mary Quarterly, XLI (1984), 24I-264.

4I Roth, Democratic Dilemma, 80-I i6; Don H. Doyle, The Social Order of a Frontier Community: Jacksonville, Illinois 1825-70 (Chicago, I978); Ryan, Cradle of the Middle Class; Donald G. 
According to a recent study by Gamm and Putnam, the legacy lasted well into the nineteenth century. Gamm and Putnam located most voluntary associations in the smaller and relatively stable cities of the Midwest and West during the latter half of the nineteenth century. Their conclusions, based on close analyses of city directories and associational membership lists, challenge the assumption that industrialization, urbanization, and pluralism were the primary motives for forming associations. In their view, "America's civic core was in the periphery, away from the big cities and outside the Northeast" during the seventy years following the Civil War. In essence, social capital flourished in the small, homogenous cities of the Old Northwest.

Gamm and Putnam do not explain this phenomenon. It might well be a legacy of the northeastern elite's associationbuilding efforts during the first half of the century. After all, the Midwest was the site of the Standing Order's first experiments in creating social order through voluntary organization. If this explanation is true, it helps to reconcile Gamm and Putnam's view with Skocpol's. She criticized Gamm and Putnam's "small-is-beautiful” paradigm, pointing instead to the expansion of the federal state and the activities of translocal organizers as the primary causes of associational development. The efforts of the cMs suggest, however, that both perspectives have merit. Organizations like the CMS provided the financing and the personnel that helped frontier settlers to organize themselves. In turn, frontier towns developed their own conception of how to create a social order that endured throughout the nineteenth century and into the twentieth century, as Gamm and Putnam documented. The local conditions and the needs of the frontier combined with the ambitions of eastern elites to develop the rich associational life that characterized nineteenth-century middle America. ${ }^{42}$

Mathews, "The Second Great Awakening as an Organizing Process, I780-I 830: An Hypothesis," American Quarterly, XXI (I969), 23-43. See also T. Scott Miyakawa, Protestants and Pioneers: Individualism and Conformity on the American Frontier (Chicago, 1964). Boyer, Urban Masses and Moral Order; Joseph F. Kett, Rites of Passage: Adolescence in America 1790 to the Present (New York, 1977).

42 Gerald Gamm and Putnam, "The Growth of Voluntary Associations in America, I840I940," Journal of Interdisciplinary History, XXIX (I999), 5 I I-557; Skocpol, Marshall Ganz, and Ziad Munson, "A Nation of Organizers: The Institutional Origins of Civic Voluntarism in the United States," American Political Science Review, XLIV (2000), 527-546; Skocpol, "How 
Americans' experience with voluntary association shows how a society in which, as Wood wrote, "no one was really in charge," could discover "harmony emerging out of such chaos." Connecticut's Standing Order concluded from both their frontier experience and their later adoption of similar strategies back home that voluntary horizontal networks might effectively produce social capital, or the networks that facilitate trust, social cooperation, reciprocity, and social solidarity. Voluntary associations and churches helped to shape the mores of America's growing middle class and, in turn, those same institutions allowed middle-class Americans to become participants in forging social order. This social order, however, was precarious. The very mechanism that formed it could challenge it. Antebellum America saw voluntary associations used in both capacities. In Taylor's framework, the CMS contributed to secular modernity by replacing the social order's natural foundations with human artifice. Regardless of how we characterize the new social order, it has had a lasting legacy on American culture and thought. ${ }^{43}$

Americans Became Civic," in idem and Fiorina (eds.), Civic Engagement, 27-7I; idem, Diminished Democracy, 32, 37, 72-73, 89-98.

43 Wood, Radicalism of the American Revolution, 359. 